Valiullina Z. V., PhD in Economics, Associate Professor of the Department of International Economic Relations, National University of Water and Environmental Engineering, Rivne, Ukraine

ORCID ID: 0000-0002-1989-5583

e-mail: z.v.valiullina@nuwm.edu.ua

\title{
Identification of Features of an International Institute in the Activities of Corporations
}

\begin{abstract}
Introduction. Under present-day conditions of the development of the world economy there is taking place the constant change of the structure and role of key institutes. There occur the changes of the system which are determined by evolution processes and phenomena. In the first place, such changes cause the distribution of influence levers on the world economic development in the direction of strengthening of the role of corporations.

Purpose. The aim of the research is to reveal the directions and forms of international institutes in the activity of present-day corporations.

The theoretical and methodological basis of the research is the fundamental principles of the present-day economic theory and innovation development of economic entities, scientific works by scholars, normative and legislative acts. The following methods were used in the process of the research: theoretical generalization (to enlighten theoretical and methodological basis of information-institutional medium of corporations' activity of the world market), induction, deduction (to investigate the fundamentals of the activity of corporations as institutes), systemic approach (aimed at discovering signs of an international institute in the activity of present-day corporations), graphic one (aimed at making demonstrative presentation).

Results. There were formed the main signs, directions and forms of present-day corporations as an institute. It has been proved that corporations operating in the sector of technologies create new institutes which determine key trends of socioeconomic development of a state. It has been determined that corporations in the sector of information-communication technologies create and change the institutional medium of international business. These have been singled out the institutional manifestations of activities of corporations in the world economy. These has been studied the interaction between technologies and the increase in labor productivity.

Conclusions. The suggested results of the research determine present-day corporations as a unique institute with complicated interrelationships in the inner production and sales network and interdependencies in the external medium.

The results of the research determine the role of large corporations as a specific institute of the contemporary world economic development which will contribute to the intensive growth of various markets and will create the value of business.
\end{abstract}

Keywords: institute; institutionalization; informatization; corporation; technology.

Удк 330.837:330.341.1

Валіулліна 3. В., кандидат економічних наук, доцент кафедри міжнародних економічних відносин, Національний університет водного господарства та природокористування, м. Рівне, Україна

\section{Виявлення ознак міжнародного інституту в діяльності корпорацій}

Анотація. Метою дослідження є виявлення напрямів та форм міжнародних інститутів в діяльності сучасних корпорацій, визначення проявів інституцій в діяльності корпорацій у світовій економіці, а також ознак сучасних корпорацій як міжнародного інституту. Теоретичною і методологічною основою дослідження $\epsilon$ фундаментальні положення сучасної економічної теорії та інноваційного розвитку суб'єктів господарювання, наукові праці вчених, нормативні та законодавчі акти України та країн світу з питань формування інформаційно інституційного середовища діяльності корпорацій. У процесі дослідження використовувалися такі методи: теоретичного узагальнення (для висвітлення теоретико-методологічних основ інформаційно-інституційного середовища діяльності корпорацій, світового ринку); індукції, дедукції (для дослідження основ діяльності корпорацій як інституції); системний підхід (з метою виявлення проявів ознак міжнародного інституту в діяльності сучасних корпорацій); графічний (з метою наочного зображення). Сформовано основні ознаки, напрями та форми прояву сучасних корпорацій як інституту. Доведено, що корпорації, задіяні у секторі технологій формують нові інститути, які визначають ключові тренди соціально-економічного розвитку держави. Визначено, що корпорації зі сектору інформаційно-комунікаційних технологій формують та змінюють інституційне середовище міжнародного бізнесу. Виокремлено інституційні прояви діяльності корпорацій у світовій економіці. Досліджено взаємодію між технологіями та приростом продуктивності праці. Запропоновані

Стаття надійшла до редакції: 10.02.2019

Received: 10 February 2019 
результати дослідження визначають сучасні корпорації як унікальний інститут зі складними взаємозв'язками у внутрішній виробничо-збутовій мережі та взаємозалежності у зовнішньому середовищі. Отримані результати дослідження визначають роль великих корпорацій як особливого інституту сучасного світогосподарського розвитку, який сприятиме інтенсивному розвитку різних ринків.

Ключові слова: інститут; інституціоналізація; інформатизація; корпорація; технологія.

Formulation of the problem. Under present-day conditions of the development of the world economy there is taking place the constant change of the structure and role of key institutes, at the same time there arises a permanent need to analyze changeable conditions of the external medium - the discovery of new players on the international markets, of new products, achievements of scientific and technological progress, of changes in the interrelations of the state and the corporative sector, the interaction of national economies in the conditions of globalization, the integration and the internalization of the world economy. There occur the changes of the system which are determined by evolution processes and phenomena. In the first place, such changes cause the distribution of influence levers on the world economic development in the direction of strengthening of the role of corporations. International corporations become the main factor and dynamic force of economic globalization at the expense of locating parts and stages of the production process on the territory of different countries. Their intensive activity reflects the aggravation of international competition as well as deepening of international labor distribution.

An analysis of modern research and publications. A great number of scientific works of both methodological and applied character have been devoted to the problems of institutionalization in the last ten years. Starting from the XXI century it is possible to speak about the influence of globalization processes on the deformation of institutional paradigm in world economy. The major contribution to the development of present-day methodology of institutionalization was made by Ukrainian scholars, in particular by A. Chukhno [1], V. Yakubenko [2], A. Tkach [3], V. Tarasevych [4], O. Ivashyna [5], etc. In the above mentioned research papers the approaches were developed concerning the formation of the institutional paradigm due to which we have got the possibility to carry out the analysis of the present-day processes of economic transformation.

The work by N. Cherkas [6] mentions that the increase in the level of added value generated in the country is to be one of priorities of state policy. However, O. Khilukha [7] marks that the right organization of the system of corporative management is possible under the interaction between institutes of management and ownership.

The basis of the institutional medium of the world economy is described in the work by N. Dalevska [8].
However, the issues of theoretical and applied character concerning the recognition of the activity of corporations as an institutional entity remain debatable and have not been studied sufficiently. This makes the subject of this research paper actual and correspondingly defines its aims and structure.

Setting objectives. The aim of the research is to define the directions and forms of international institutes in the activity of present-day corporations, to determine the institutions in corporations' activity in the world economy and the features of contemporary corporations as an international institute.

Presentation of the main research material. The research into institutional fundamentals of the activity of present-day corporations becomes impossible without taking into account the influence of informatization factors, as the international market - as the main element of the world economic activity - is an information institute. Therefore, the main distinctive features of the modern stage are the attempts to intellectualize and informatize the productive systems at the expense of replacing consumptive power resources by information and intellectual resources and scientific technologies. In our opinion, this is a new and the most important factor of transforming corporations into a key institute of self-organization of the world economic complex.

The table 1 contains basic features, directions and forms of present-day corporations as an international institute.

In a new geo-economic landscape there are being formed several centers of power distribution, the number of participants of international economic relations increases, substantial changes are being observed on international markets in terms of high technologies. The largest corporations in the sphere of technologies have achieved high indices of incomes, assets, the number of clients, staff and revenues. Thus, the Indian telecommunication corporation "Bharti Airtel" has about $310 \mathrm{mln}$ subscribers all over the world - the number which is compatible with the population of the USA. The number of monthly active users of "Facebook" is compatible with the population of China; and corporation "Google" processes about 4 billion enquiries a day. The above said facts confirm the author's statement that present-day corporations are becoming an international institute such as states, regional associations etc. 
Електронне наукове фахове видання з економічних наук "Modern Economics», №13 (2018), 55-60 https://modecon.mnau.edu.ua | ISSN 2521-6392

Table 1 Features of present-day corporations as an international institute

\begin{tabular}{|l|l|}
\hline \multicolumn{1}{|c|}{ Direction } & \multicolumn{1}{c|}{ Form of manifestation } \\
\hline $\begin{array}{l}\text { Formation and } \\
\text { distribution of } \\
\text { productive } \\
\text { resources }\end{array}$ & $\begin{array}{l}\text { Growth of efficiency and productivity of using qualified working force of adopting countries; growth of a } \\
\text { share of scientific-technological component at all stages of production process; the transformation of } \\
\text { information and communication technologies into a key element of production-sales activity; orientation at } \\
\text { innovations as resources }\end{array}$ \\
\hline $\begin{array}{l}\text { Creation of } \\
\text { additional } \\
\text { competitive } \\
\text { advantages }\end{array}$ & $\begin{array}{l}\text { Substantial changes in the state of companies and branches on the basis of creating segments of higher } \\
\text { technological structure in economies of leading countries on the basis of rapid growth of the role of ICT, growth of } \\
\text { role of education and science; strengthening of corporations positions operating in intellectual consuming sectors; } \\
\text { growth of share R \& D and innovations in the final project. }\end{array}$ \\
\hline $\begin{array}{l}\text { Interaction with } \\
\text { national } \\
\text { economies }\end{array}$ & $\begin{array}{l}\text { Activation of corporations' participation in integration processes both within regional associations and in } \\
\text { structures of other regions; strengthening of the interaction of state and corporative sectors at the expense } \\
\text { of corporations' participation in associations, opening of agencies in national and supranational structures, } \\
\text { the use of consulting organizations for lobbying own interests and search for compromises in terms of } \\
\text { liberalizing the transportation of goods, services and capitals. }\end{array}$ \\
\hline $\begin{array}{l}\text { Formation of } \\
\text { global } \\
\text { transnational } \\
\text { medium }\end{array}$ & $\begin{array}{l}\text { Formation of mighty corporative network on the basis of developing partner relations with companies of } \\
\text { adopting countries; the competition of corporations with local firms which are already subdivisions of other } \\
\text { large corporations; winning of new markets and diversification of international business at the expense of } \\
\text { takeovers, particularly in information and highly technological sectors }\end{array}$ \\
\hline
\end{tabular}

Source: author's development

Some of important features of the activity of modern corporations as institutes which change the world economy and its medium are the rates of industrial export which reflect flows of technological goods and services from countries-donors to countries-recipients. Thus, by
2016 the rates of the export of technological products and services only in the USA alone amounted to $14 \%$ of the total export and equaled approximately 209 billion USA dollars (fig. 1).

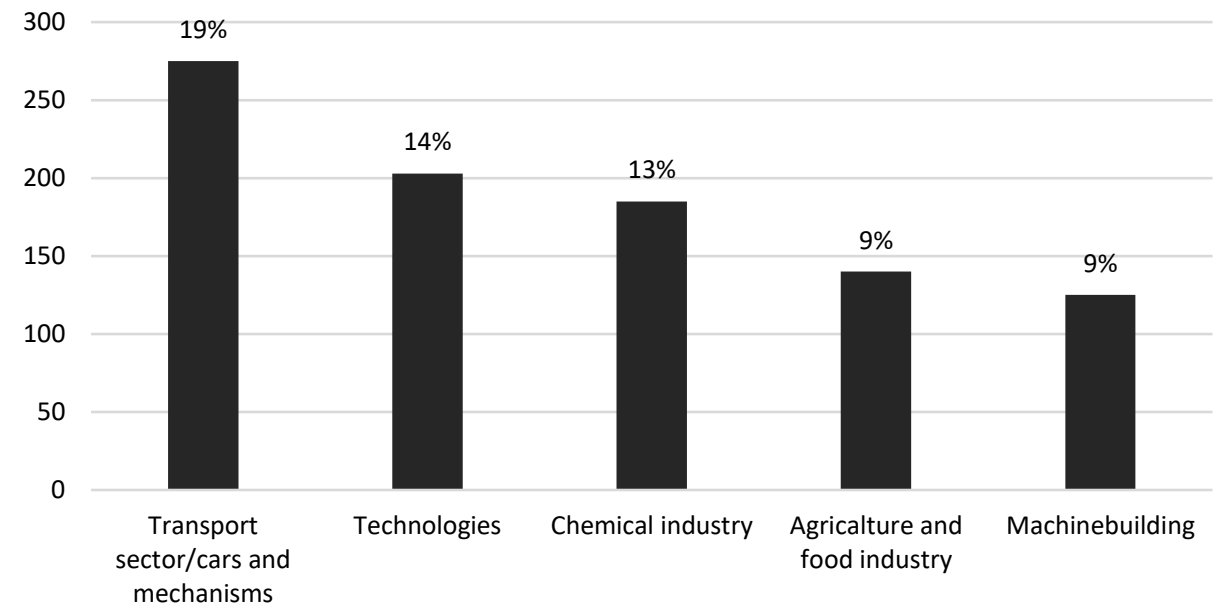

Figure 1 - Distribution of the USA industrial exports by industry, billion US dollars, 2016

Source: designed by the author on the basis of sources [9]

Thus, it is possible to state that from every 4 USA dollars obtained in the technological industry 1 USA dollar comes from export. Besides, such export by itself stimulates and generates substantially more profit abroad - over $50 \%$ of its own value. For many technical experts in export there is even larger percentage of sales, some of them generating more than half of their profits abroad.

Corporations of the sector of information technologies exert an important chain effect on the global economy. Generating high profit and employing workers with relatively high average wages IT-sector helps other sectors as well to increase productivity, to work more efficiently and introduce innovations at a faster rate. Beside this, information technologies are a dynamic force of the development at other markets and may create the transformation value of business in a wide sphere of branches and markets. It is because of the above factors the role of large corporations in this sector as a particular institute of modern world economic development is extremely important, and this tendency is predicted to be preserved in the next years (fig.2). 


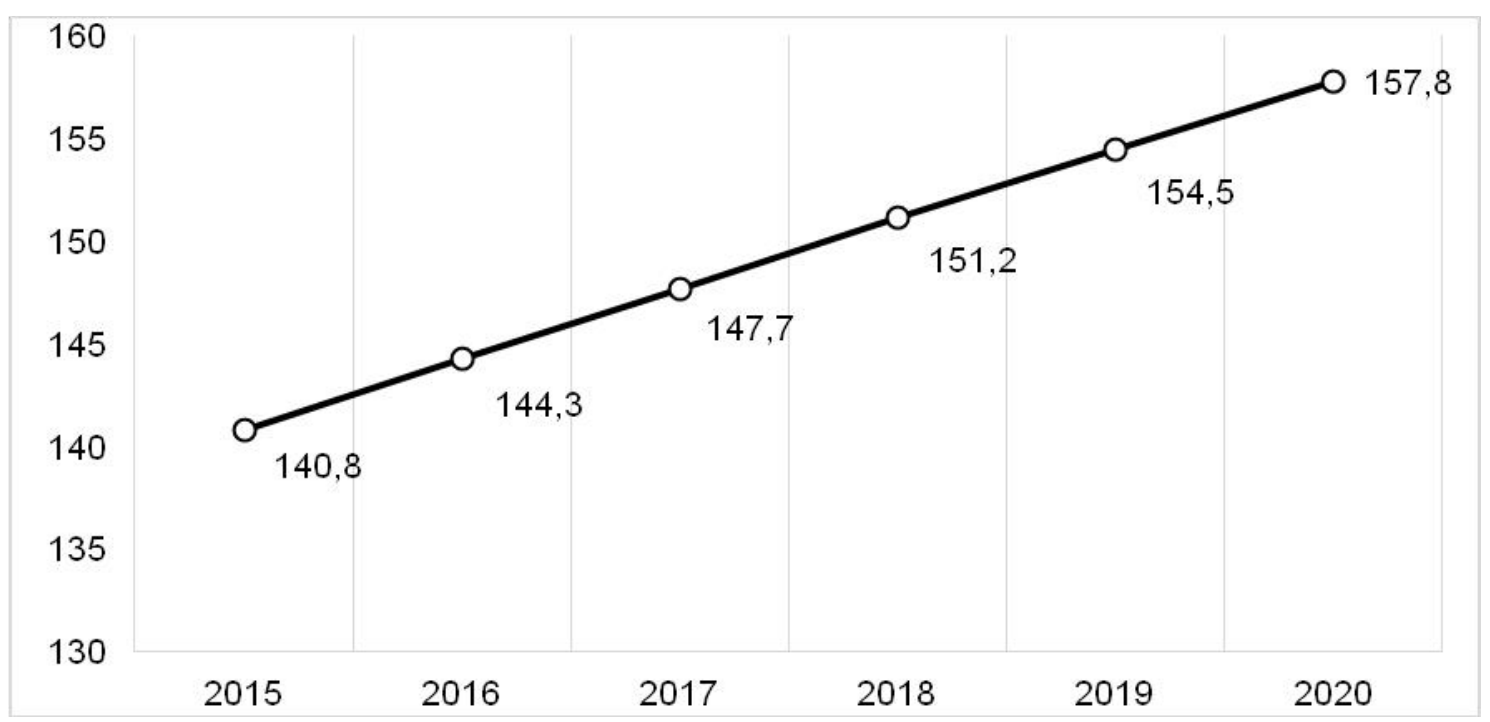

Figure 2 - Costs of IT corporations, 2015-2020 (forecast), billion US dollars

Source: designed by the author on the basis of sources [10]

Nowadays IT corporations change the structure and nature of the world economy and the life of present-day society. Artificial intelligence, e-commerce, business services and data protection are among the most important tendencies that affect the development of modern corporations; to remain among the leaders of global business all of them observe attentively the changes in the environment and try to successfully implement their own innovation potential which permits to react quickly to changes in the structure of consumption demand, to provide high quality servicing of their own products and support their own leading positions. In table 2 we shall single out the institutional identification of the activity of corporations in the world economy.

Table 2 Identification of the activities of corporations as institutes in the global economy

\begin{tabular}{|c|c|}
\hline Spheres & Manifestations of modern corporations as institutes \\
\hline Labor resources & $\begin{array}{l}\text { The absolute majority of workers employed in industry and the sector of services will use automated assistance for } \\
\text { carrying out their own functions, active use the functionality of services and the emergence in them of various } \\
\text { functions diminishes the list of performed works and their volumes. }\end{array}$ \\
\hline Retail & $\begin{array}{l}\text { The substantial number of retail chains will be forced to curtail their own scales due to uneven competitive struggle } \\
\text { with services of on-line purchases, namely, small companies. An important role is played by the development of tools } \\
\text { for business and the creation of a platform for connecting companies with customers in order to increase the volume } \\
\text { of online sales. }\end{array}$ \\
\hline Information & $\begin{array}{l}\text { The absolute majority of large corporations consider themselves as companies the value of which is based on } \\
\text { information assets. Information is the source of additional competitive advantages which permits to make quick } \\
\text { decisions, to automate business processes, and, correspondingly to decrease the load on the personnel. }\end{array}$ \\
\hline Operation models & $\begin{array}{l}\text { Modern corporations successfully use and apply developments for their own quick completely functional operation } \\
\text { models in digital space. The development of technologies of artificial intelligence is the main guarantee of success in } \\
\text { international business. On this basis a huge number of companies all over the world make their own decisions which } \\
\text { are quickly implemented in spheres of marketing, client servicing, technical support, etc. }\end{array}$ \\
\hline Leadership & $\begin{array}{l}\text { The guarantee of leadership on international markets for the majority of corporations is the use of manifestations } \\
\text { and consequences of digital transformation - first of all, the use of present-day technologies for increasing the } \\
\text { productivity and value of the company in the present world. Among the most important effects are the reduction of } \\
\text { expenditures, the growth of the quality of services and products and the growth of productivity. }\end{array}$ \\
\hline
\end{tabular}

Source: author's development

At present, the digital transformation forms a new identification of an institute in large corporations, in the information sector in particular, and serves a locomotive of the development of world economy. Thus, one can speak about the next wave of introducing innovations which is to create favorable conditions for developing technologies. As before, IT-technologies ensure the increase in labor productivity, the possibility to spend less and to earn more.

However, among new features of the institute the following should be singled out: 
- innovations become an independent source of added value and the share of production and other traditional spheres decreases;

- information and its processing play a key role, there takes place a huge development of the information market, and the goods have no longer any material envelope;

- new expectations of consumers force producers of goods and services to adjust practically everything to possible demands - ranging from a product to the ways of delivering, this forces companies to create technological platforms which combine the demand and supply, production and development, sale and marketing. In this case, the key moment is not only the introduction of technologies but understanding by corporations of the necessity to overview their own attitude to the way they function.

In present-day leading corporations, in particular ITsector, information and communication technologies change the models of communication between people, also between people and organizations (the authorities, small and large business, wholesale trade, organizations of social profile). It becomes easier to establish and support contacts; it is possible to interact with one another at any distance. The spread of information technologies takes place rapidly, although more evenly than the distribution of incomes. Individuals get instruments for direct interaction avoiding intermediaries. Migration on-line takes place in the spheres which used to be accessible only off-line, for example, state services and education. Society becomes dependent on smart-gadgets, such as mobile telephones and tablet computers in everything. With their help it is possible to implement a great number of tasks at any place and at any time ranging from communication, shopping, leisure and checking mail to banking settlements, education and GPS-navigation.

The behavior of users is evolving: thus, 10 years ago creating a "Facebook" profile changed people's life. Later "Instagram" and "Twitter" called for sharing personal information continually. Today the era of trekking has become dominant: we inform society when we got up, how much we walked, how we walked the dog, etc. Their consumers spend practically all their free time with gadgets.

Thus, the use of digital technologies at all stages of production and sales activity of modern corporations has become a key format in the interaction with clients. The ability to find and correctly use the valuable information from the received data permits modern corporations to better understand the demands, to reveal inquiries of consumers and to efficiently implement all possible competitive advantages. Analyzing huge amounts of data companies may reveal substantial shortcomings in inner processes, understand how to improve the quality of products and services, change assortment and also forecast the options of further development, tendencies of demand, proposals and prices formation. On the whole, it is possible to sum up key changes, caused by changing the medium of corporations activity and to reveal the manifestations of features of an international institute in the activity of modern corporations (table 3 ).

Table 3 Identification of features of an international institute in the activities of modern corporations

\begin{tabular}{|c|c|}
\hline Institute & Manifestations \\
\hline Corporations & $\begin{array}{l}-52 \% \text { of companies from Fortune- } 500 \text { have been absorbed or bankrupted since } 2000 \\
\text { - the term of operation of large corporations has already decreased by } 1,5 \text { times; } \\
\text { - the activity of } 1 / 3 \text { companies from top- } 500 \text { was undermined by new technological platforms. }\end{array}$ \\
\hline Personnel and employment & $\begin{array}{l}\text { - companies oriented at growth strive for creating possibilities for training their personnel; } \\
\text { - knowledge and skills which were important } 10 \text { years ago are morally old-dated in relation to } \\
\text { tendencies of a new world model; } \\
-60 \% \text { of new vacancies on the market require highly qualified staff, at present special skills are } \\
\text { mastered by only } 20 \% \text { of the population. }\end{array}$ \\
\hline Spreading information & $\begin{array}{l}\text { - one of the most important channels of advancing information leaders in social networks - } 60 \% \\
\text { consumers listen to recommendations; } \\
-10 \text { years ago mass media required a day or more for spreading information; today - one click } \\
\text { of a mouse is enough; } \\
\text { - the Internet has become massively used in only } 7 \text { years; it took } 30 \text { years for telephone and } \\
\text { radio to become common for a quarter of the USA population. }\end{array}$ \\
\hline Communications & $\begin{array}{l}\text { - in most developed countries about } 40 \% \text { of daily communication happen via digital gadgets; } \\
\text { - almost } 80 \% \text { consumers all over the world have smart phones; } \\
\text { - the possibility of making purchases in various regimes actively is developed is in trade point, } \\
\text { via mobile telephone, via computer with a possibility of seamless transfer; } \\
\text { - the use of clever chat-botes for communication with buyers; } \\
\text { - connection of the virtual or the added reality for shopping. }\end{array}$ \\
\hline
\end{tabular}

Source: author's development

Conclusions. Hence, processes of globalization and transnationalization lead to the transformation of basic institutes which in its turn cause a certain destruction of national economic state sovereignty and the emergence of principally new supranational economic associations - modern mighty corporations which are increasingly acquiring the features of new independent institutes with complicated interrelations in the domestic production and sales network and interdependence in the external medium. 
The research has proved that digital transformation is guaranteed by the fact that a human being and any business have access to technologies and computer capacities which used to seem inaccessible. Today these are technologies themselves which provide any company with the possibility to change its own business and model in such a way so that to differentiate itself from the world market. The direction of further research may be the systematization of models of corporations' activity as an international institute.

\section{Література:}

1. Чухно А. Інституціоналізм: теорія, методологія, значення. Економіка України. 2008. № 6. С. 4-13.

2. Якубенко В. Д. Базисні інститути у трансформаційній економіці : монографія. К. : КНЕУ, 2003. 252 с.

3. Інституціональна парадигма цивілізаційного розвитку : монографія: у 4 кн. / За ред. А Ткача. Запоріжжя : ГУ “ЗІДМУ”, 2007. 276 c.

4. Тарасевич В. Институциональная срединность Украины. Інституціональний вектор розвитку. 2008. № 1 (1). С. 13-21.

5. Івашина О. Ф. Інституціоналізація економічного розвитку : монографія. Дніпропетровськ : Наука та освіта, 2009.283 с.

6. Черкас Н. І. Особливості створення доданої вартості в умовах глобальної мережевізації виробництва. Економіка розвитку. 2018. № 1 (85). С. 37-48.

7. Хилуха О. А. Система корпоративного управления предприятием. Економіка розвитку. 2017. № 2 (82). С. 97-103.

8. Далевська Н. М. Інституціоналізація інтересів акторів міжнародних відносин на засадах стратегічного партнерства. Проблеми економіки. 2015. № 1. С. 22-26.

9. Regional distribution of IT spending. It Industry Outlook 2018. URL: https://www.comptia.org/resources/it-industry-trends-analysis

10. IT Market Statistics and Trends. URL: https://www.ironpaper.com/webintel/articles/it-market-statistics-and-trends/

11. Selmier T. W., Oh Ch. H. International business complexity and the internationalization of languages. Business Horizons. 2012. Vol. 55. Issue 2. P. 189-200.

12. Kordos M., Vojtovic S. Transnational Corporations in the Global World Economic Environment. Procedia - Social and Behavioral Sciences. 2016. Vol. 230. P. 150-158.

\section{References:}

1. Chukhno, A. (2008). Institutionalism: theory, methodology, meaning. Ukraine economy, 6, 4-13 [in Ukrainian].

2. Yakubenko, V. D. (2003). Bazysni instytuty u transformatsijnij ekonomitsi. Kyiv: KNEU [in Ukrainian].

3. Tkach, A. (2007). Instytutsionalna paradyhma tsyvilizatsijnoho rozvytku. Zaporizhzhia: HU “ZIDMU” [in Ukrainian].

4. Tarasevych, V. (2008). Institutional middle of Ukraine. Instytutsionalnyi vektor rozvytku, 1 (1), 13-21 [in Ukrainian]

5. Ivashyna, O. F. (2009). Instytutsionalizatsiia ekonomichnoho rozvytku. Dnipropetrovsk: Nauka ta osvita [in Ukrainian].

6. Cherkas, N. I. (2018). Features of creation of added value in conditions of global networking of production. Ekonomika rozvytku, 1 (85), 37-48 [in Ukrainian].

7. Khilukha, O. A. (2017). System of the corporate management of enterprise. Ekonomika rozvytku, 2 (82), 97-103. [in Ukrainian].

8. Dalevska, N. M. (2015). Institutionalization of the interests of actors in international relations on the basis of strategic partnership. Problemy ekonomiky, 1, 22-26 [in Ukrainian].

9. Regional distribution of IT spending. It Industry Outlook 2018 (2018). Retrieved from https://www.comptia.org/resources/it-industry-trends-analysis.

10. IT Market Statistics and Trends (2016). Retrieved from https://www.ironpaper.com/webintel/articles/it-market-statisticsand-trends/

11. Selmier, T. W. \& Oh, Ch. H. (2012). International business complexity and the internationalization of languages. Business Horizons, 55 (2), 189-200. DOI: https://doi.org/10.1016/j.bushor.2011.11.006

12. Kordos, M. \& Vojtovic S. (2016). Transnational Corporations in the Global World Economic Environment. Procedia - Social and Behavioral Sciences, 230, 150-158. DOI: https://doi.org/10.1016/j.sbspro.2016.09.019. 